\title{
What are the Differences among Adult Students Regarding Self-Confidence and Motivation to Learn?
}

\author{
Leticja Papa-Gusho, PhD Candidate
}

\author{
Pedagogy-Psychology Department \\ Social Science Faculty, Tirana University \\ E-mail: lpapagusho@yahoo.co.uk
}

Doi:10.5901/jesr.2013.v3n2p351

\begin{abstract}
Nowadays, the number of adult students, who want to graduate in public universities in our country is increasing rapidly. But, what are the characteristics of these students regarding self-confidence and motivation to learn? What are the differences that exist in between adult students groups who have a secondary education degree, those with a university degree and the ones with a master degree? This article aims at giving an overview of the differences that exist between the group of adult students who have finished high school, the group of adult students who have finished the university and those with a master degree, regarding self-confidence and motivation learn. Statistical analyzes were performed using SPSS program, and more precisely, the comparison between groups was performed using ANOVA parametric test-s. In conclusion, from the results it was confirmed that, there are statistically significant differences in terms of self-confidence among high school and university groups. On the other hand, from the data collected we were confirmed that, there were no such significant differences in between the groups as far as the issue of the motivation to learn is concerned.
\end{abstract}

Key words: adult students, self-confidence, motivation to learn

\section{Introduction}

Self-Confidence and motivation to learn are two elements that are very important for adult students. Both, confidence in your own abilities to achieve something and motivation to learn, can be very important for adult students to make hard decisions in their everyday life. (Keller, 1986). On the other hand, there are many studies which show, that confidence varies significantly between diverse groups of adult students.

Thus, Leary, M. \& Downs, D. (1999) in their study have identified that individuals self-confidence to achieve anything tends to increase, if their previous academic achievements have been positive.

Moreover, studies have shown that adults choose to participate in an activity that is related to learning if they are really motivated to do so (Tennant \& Pogson, 1995). According to these authors, the lack of knowledge and skills during the active life is a very powerful force to give an impetus to learning opportunities, since learning is already firmly entrenched as a key element in all life stages.

Again, according to these authors, there are a number of factors that can lead adults to become part of the learning community and to motivate them to learn. Among these factors may be mentioned social changes, competition in the profession, general social competition or family breakdown.

The main purpose of this article is to give an overview of the differences that exist between the subgroup of adult students that have experienced high school education, adult student subgroup that have experienced university studies and those with masters', in terms of self-confidence and motivation to learn.

This article is part of the study, which among other things, aims at studying the self-confidence and motivational factors of adult students.

In the process of this study, by means of the survey, are highlighted elements of self-confidence and motivation at adult students. Then, by performing statistical analysis using the SPSS program, version 10, are derived the student groups in terms of the differences that exist between them. 


\section{Theoretical Framework}

Studies show that self-perception (self-confidence, perception of personal learning skills, level of competence and expectations of being able to pass a course) is significantly related to participation in adult education (Skaalvik \& Finbak, 2001).

Research related to this tradition shows that people have a tendency to avoid situations and activities that require power levels which people believe not to have not. Efforts to resolve the difficulties dealing with people and their choices are influenced by their self-efficacy. Individuals who have low expectations of their powers will reduce their input or soon will be withdrawn when they encounter problems.

According to Skaalvik \& Finbak (2001), participation in adult education is an element that has its own rules and depends a lot from self-confidence and motivation to learn. Therefore, academic self-confidence can be of great importance to participation in learning activities once compulsory schooling is done. It affects requiring for a higher degree of education and participation in adult education courses. Research to young people for example, have shown that academic self-confidence is systematically related to the selection and completion of schooling (Hackett, 1995).

In a school situation, few expectations of personal skills to master a particular subject can result in a dilemma. On the one hand, major efforts will improve everyone's chances to achieve better results, while on the other hand, poor results, despite the high input, can be seen as an indicator of low ability. Therefore, when perceptions of competence are low, input may seem intimidating, which can lead to a need to protect selfperception (Courtney,S. 1991).

Among school-age children, low expectations for mastery of a subject can lead to reduced efforts as part of defense self-confidence. Among adults who have a choice, low expectations to master subject can lead to non-participation in education or abandonment if mastery expectations for that subject continue decrease while they attending this course (Skaalvik \& Finbak, 2001, Pg, 8).

\section{Methodology}

\subsection{Procedure and sample}

This study has been carried out through a quantitative and a qualitative research model. In this paper are presented only the data of the quantitative research. Withdrawal of the sample from the population is made with sample stage method. Initially, by means of these methods were selected four higher education institutions in the country and then is selected the sample from the group of adult students that are frequenting the parttime study in this institutions. The general population that served for this sample is made of adult students who are actually frequenting the part-time 2011-2012 academic year of the public educational system in the universities of Tirana, Korça, Elbasan and Durrës. This population counts approximately 9697 just for one year, times the four years of the studies, equals to 38788 students. Even though, in all the universities there are actually enrolled just 25.000 students for the four years. A sample of 400 participants from this population is also covered. (Cohen, Manion \& Morrison, 1970, p 94).

As mentioned above, the stage probability sample is used to select the sample from this population. It involves selecting the sample in stages, that is, taking sample from sample. In other words, with the stage selection sample we select firstly a number of universities at random. Then within the selected universities, we randomly select a number of faculties. After this, even within the selected faculties we randomly pick the years (first year, second year, etc). Finally, we select a number of students out of the studying years. By means of this method is selected even the sample that represents the population features. Out of 400 adult students of the sample, just 130 are men and the other 270 are women, or $32.5 \%$ are men and $67.5 \%$ are women. The largest number of participants, i.e., $73 \%$ is $25-39$ years, followed by the $40-49$ years old, who comprise $17 \%$. Then comes the age group up to 24 years $6 \%$, and in the end is the age group 50-59 years $3.8 \%$. Out of 400 participants in the study, $59 \%$ of the adult students make the group of the married people, i.e., the largest one. Some $33,5 \%$ form the group of the unmarried ones, of whom $5.3 \%$ are cohabitating and two other groups divorced and widow compose only $1 \%$ of the sample. 
The educational level of the participants in the study varies from $36 \%$ who have got a high school degree, to $55 \%$ who have got just the university degree and attend this school as a second university and just $8 \%$ of them have a master degree. Only $0.5 \%$ of the adult students who are frequenting part-time studies have declared that the specialized courses mean to them a higher level of education. Out of 400 participants, 150 adult students or $37.5 \%$ are unemployed, 242 adult students or $60.5 \%$ are employed, and only 8 students or $2 \%$ are households.

\subsection{Instrumentation}

The instrument used for gathering the data is a questioner made of some rubrics. The questionnaire is conducted by 400 respondents who in 35-40 minutes completed it. Initially participants were informed about the purpose of the study and clarified that the survey data will be used only for academic purpose. Given that self-confidence and motivation to learn are the only focus of this article, only the elements of the questionnaire will be represented. Those are arranged in a scale form, where students should circle the answer from strongly disagree to strongly agree, according to their level of agreement.

\subsection{Sources of error}

The way this research was carried out intended to minimize non real results. However, like most of the studies made in the field of adult education, even this one is self-report based. As a result, the findings depend even on the students' acquisition of the questions in the survey as well as on the degree of sincerity they have completed the instrument with.

\subsection{Research ethics}

During the implementation of this study, all the stages of research ethics have been followed. It has firstly been taken the permission of the structures in charge of the faculties where the instrument was conducted. Subsequently, a sensitization of the research and its goal was done to the participants before they filled the instrument. They were guaranteed anonymity and asked whether they wanted to participate voluntarily in the study. Furthermore, participants who did not want to be part of the study, did not meet the instrument.

\subsection{Results and discussion}

ANOVA was conducted to examine statistical significance difference in the mean scores across groups and to answer the question of how students differ in terms of self-confidence and motivation to learn in relation to those groups.

The following assumption about the data must be met to conduct ANOVA (Pallant 2010). According to this author, the observations must be normally distributed on the dependent variable, but with large sample size, and in this case the sample size is 400, the violation of this assumption should not cause any major problems. The population variances for each group are equal and the observations in each group are individually administered. The data were initially treated for homogeneity of variance. As shown in the results of table 1 and table 2 for the treatment of data for homogeneity of variance Levene test has been conducted. From table 1 and 2, the significance value is greater than 0.05 , so in this case it is not violated the assumption of homogeneity of variance.

Table 1. Levene's test for "self-confidence"

Test of Homogeneity of Variances

\begin{tabular}{|c|c|c|c|}
\hline Levene Statistic & df1 & df2 & Sig. \\
\hline .070 & 2 & 347 & .932 \\
\hline
\end{tabular}


Table 2. Levene's test for "Motivation to learn"

Test of Homogeneity of Variances

Motivation to learn

\begin{tabular}{|r|r|r|r|}
\hline Levene Statistic & df1 & df2 & Sig. \\
\hline .470 & 2 & 332 & .625 \\
\hline
\end{tabular}

ANOVA test (One-Way ANOVA) was performed to see if there are any differences between groups with high school education, university and master in relation to self-confidence variable. Post-hoc comparison test using the Tukey procedure was carried out to determine exactly where the differences between the groups with high school education, university and master exist.

Table 3. Descriptive statistics for self-confidence between groups.

\section{Descriptives}

\section{Self-Confidence}

\begin{tabular}{|c|c|c|c|c|c|c|c|c|}
\hline & \multirow[b]{2}{*}{$\mathrm{N}$} & \multirow[b]{2}{*}{ Mean } & \multirow[b]{2}{*}{ Std. Deviation } & \multirow[b]{2}{*}{ Std. Error } & \multicolumn{2}{|c|}{$\begin{array}{c}35 \% \text { Confidence Interval fol } \\
\text { Mean }\end{array}$} & \multirow[b]{2}{*}{ Minimum } & \multirow[b]{2}{*}{ Maximum } \\
\hline & & & & & Lower Bound & Upper Bound & & \\
\hline High school & 122 & 24.25 & 2.78 & .25 & 23.75 & 24.74 & 17 & 30 \\
\hline University & 197 & 25.10 & 2.92 & .21 & 24.69 & 25.51 & 12 & 30 \\
\hline Master degre & 31 & 25.13 & 2.90 & .52 & 24.07 & 26.19 & 18 & 30 \\
\hline Total & 350 & 24.81 & 2.89 & .15 & 24.50 & 25.11 & 12 & 30 \\
\hline
\end{tabular}

Participants were divided into three groups, according to their educational level. One was the group of students who have only the high school graduation, the other group was made of those who have a university diploma and the third one was the group of students with master degree. From Table 3, which provides the descriptive data of the answers upon self-confidence, we find out that this question has been answered by 122 students who have accomplished high school education, 197 students who have accomplished university, and attend these studies as a second program and 31 students who are graduated in masters. 350 adult students have answered the question about self-confidence, in total.

Table 4. ANOVA result for "Self-confidence"

\section{ANOVA}

Self-Confidence

\begin{tabular}{|l|r|r|r|r|r|}
\hline & Sum of Squares & \multicolumn{1}{|c|}{ df } & Mean Square & \multicolumn{1}{c|}{ F } & \multicolumn{1}{c|}{ Sig. } \\
\hline Between Groups & 58.712 & 2 & 29.356 & 3.569 & .029 \\
\hline Within Groups & 2854.076 & 347 & 8.225 & & \\
\hline Total & 2912.789 & 349 & & & \\
\hline
\end{tabular}

A one-way between-groups analysis of variance was conducted to explore if there exists any difference within groups. As indicated in Table 4, there was a statistically difference at the $p<.05$ level in self-confidence scores for the three groups: $F(2,347)=3.569, p=.029<.05$. Post-hoc comparisons using the Tukey HSD test, indicated that the mean score for group that have high school as high education $(M=24.25, S D=2.78)$ was significantly different from group that have university as higher education $(M=25.10, S D=2.92)$. 
Despite the results have proved statistically significant, the difference in mean scores between groups is relatively small.

Table 5. Tukey HSD test for "Self- confidence"

\section{Multiple Comparisons}

Dependent Variable: Self-Confidence

Tukey HSD

\begin{tabular}{|c|c|c|c|c|c|c|}
\hline \multirow[b]{2}{*}{ (I) High level of eduucation } & \multirow[b]{2}{*}{ (J) High level of eduucation } & \multirow{2}{*}{$\begin{array}{c}\text { Mean } \\
\text { Difference (I-J) }\end{array}$} & \multirow[b]{2}{*}{ Std. Error } & \multirow[b]{2}{*}{ Sig. } & \multicolumn{2}{|c|}{ 95\% Confidence Interval } \\
\hline & & & & & Lower Bound & Upper Bound \\
\hline \multirow[t]{2}{*}{ High school } & University & $-.86^{*}$ & .33 & .026 & -1.63 & $-8.12 \mathrm{E}-02$ \\
\hline & Master degree & -.88 & .58 & .276 & -2.24 & .47 \\
\hline \multirow[t]{2}{*}{ University } & High school & $.86^{*}$ & .33 & .026 & 8.12E-02 & 1.63 \\
\hline & Master degree & $-2.75 \mathrm{E}-02$ & .55 & .999 & -1.33 & 1.27 \\
\hline \multirow[t]{2}{*}{ Master degree } & High school & .88 & .58 & .276 & -.47 & 2.24 \\
\hline & University & $2.75 \mathrm{E}-02$ & .55 & .999 & -1.27 & 1.33 \\
\hline
\end{tabular}

* The mean difference is significant at the .05 level.

Taking into consideration the differences between the high school group $(M=24.25, S D=2.78)$ and the masters' group ( $M=25.13, S D=2.90$ ), it does not appear to have any significant statistical difference. The same picture appears also for the university group $(M=25.10, S D=2.92)$ and master degree $(M=25.13, S D=2.90)$.

The same analyses has been conducted even to the differences of the groups regarding the motivation to learn issue, was conducted.

Table 6. Descriptive statistics for "Motivation to learn" variable across groups.

\section{Descriptives}

\section{Motivation to learn}

\begin{tabular}{|c|c|c|c|c|c|c|c|c|}
\hline & \multirow[b]{2}{*}{$\mathrm{N}$} & \multirow[b]{2}{*}{ Mean } & \multirow[b]{2}{*}{ Std. Deviation } & \multirow[b]{2}{*}{ Std. Error } & \multicolumn{2}{|c|}{\begin{tabular}{|c|}
$95 \%$ Confidence Interval for \\
Mean
\end{tabular}} & \multirow[b]{2}{*}{ Minimum } & \multirow[b]{2}{*}{ Maximum } \\
\hline & & & & & Lower Bound & Upper Bound & & \\
\hline High school & 115 & 30.83 & 3.97 & .37 & 30.09 & 31.56 & 22 & 44 \\
\hline University & 190 & 31.05 & 4.16 & .30 & 30.46 & 31.65 & 20 & 45 \\
\hline Master degre & 30 & 31.00 & 3.73 & 68 & 29.61 & 32.39 & 22 & 36 \\
\hline Total & 335 & 30.97 & 4.05 & .22 & 30.54 & 31.41 & 20 & 45 \\
\hline
\end{tabular}

Referring to the data of table 6 , which provides the descriptive statistics of the motivation to learn question, we find out that this question has been answered from 115 students with a high school degree as higher education, 190 students with university degree and 30 adult students who have master degree as higher education. In total, this question has been answered from 335 adult students. Relying on the comparative analysis using the Tukey HSD test, it has been found that the means scores between group that has been completed high school $(\mathrm{M}=$ $30.83, S D=3.97)$ to the group that has been finished the university $(M=31.05, S D=4.16)$ and the group with master degree $(M=31.00, S D=3.73)$, for the variable of motivation to learn, did not differ significantly.

Table 7, also shows that in this case $F(2,332)=.112, p=0.894, p>0.05$ which means that these groups statistics did not differ significantly in terms of motivation to learn. 
Table 7. ANOVA result for "Motivation to learn"

\section{ANOVA}

Motivation to learn

\begin{tabular}{|l|r|r|r|r|r|}
\hline & Sum of Squares & \multicolumn{1}{c|}{$\mathrm{df}$} & Mean Square & \multicolumn{1}{c|}{ F } & \multicolumn{1}{c|}{ Sig. } \\
\hline Between Groups & 3.706 & 2 & 1.853 & .112 & .894 \\
\hline Within Groups & 5469.995 & 332 & 16.476 & & \\
\hline Total & 5473.701 & 334 & & & \\
\hline
\end{tabular}

\section{Conclusions}

In conclusion, some results can be summarized at the end of this article. From the survey conducted in the population of students who attend part-time education in some public universities in Tirana, Korça, Elbasan, and Durrës, a sample of 400 students has been drawing, through the stages sampling method. This sample was divided into three groups according to their educational. Namely, one was the group of those who have finished high school, the other the group of those who have finished university and the third the group who have finished the master studies.

To evaluate the results of all statistical tests a level limit of statistical significance of 0.05 was set. To conduct ANOVA, all the data has met assumptions. Statistical analysis of the data indicated that there is a statistically significant difference for self-confidence between the group with high school education as higher education and the university group, where $p<.05$. There is no difference between the two other groups.

As far as the motivation to learn was concerned there was not any statistically significant differences between groups of high school, university and master studies.

\section{References}

American Psychological Association (2009). Publication Manual of the American Psychological Association (6 ${ }^{\text {th }}$ ed.) Belenky, M., Clinchy, B., Goldberger, N., \& Tarule. (1986). Women's Ways of Knowing: The development of self, Voice and Mind. New York: Basic Books.

Benshof,J.M. (1991) "Nontraditional college students: An developmental look at the needs of women and men returning to school. Journal of young Adulthood and Middle Age. Vol 3.

Benshoff,J,M \&Lewis,H. (1992) "Nontraditional College Students" ERIC Clearinghouse on Wlodkowski,R.J.(1999). Enhancing Adult Motivation to Learn: A Comprehensive Guide For Teaching All Adults. (3 $\left.{ }^{\text {rd }}\right)$ San Francisco: JosseyBass

Brazziel, W.F. (1989). "Shaping higher education's future: Demografic realities and opportunities. San Francisco" JosseyBass.

Brookfield, S. (1995). Adult Learning: An Overview. International Encyclopedia of Education. Oxford, Pergamon Press.

Burgess. P. "Reasons for Adults Participation in Group Educational Activities" Quality of living Programs, University of Missouri Extension Division, Columbia, Missouri.

Burns \&Grove (1997).

Clayton, D.E., \&Smith, H, M.M (1987). "Motivational typology of reentry women". Adult Education Quarterly. Vol. 37

Cohen, L, Manion, L \& Morrison, K. (2005). Research Methods in Education ( ${ }^{\text {th }}$ ed.). Taylor \& Francis Group.

Cohen,L.Manion,L\& Morrison,K. (2000) "Research Methods in Education" $5^{\text {th }}$ Edition. Routledge Falmer,Taylor\&Francis

Courtney,S. (1991) "Why Adult Learn: Toward a theory of participation in adult Education. New York: Routledge, 1991

Creswell,J.W. (1994). "Research Design: Qualitative and Quantitative approaches. Thousand Oaks: Sage

European Commission (2003). "Implementing Lifelong Learning strategies in Europe". ETF

Francois, E. (2010) "Motivational Factors and Worldview Dimensions Associated with Perceptions of Global Education Initiatives by U.S. College Professors", University of South Florida.

Galerstain.C\& Chandler.J (1982). "Faculty Attitudes toward Adult Students (Vol 30, Nr3), Taylor \& Francis, Ltd.

Garcia,L \& Fredricks, J (2008) "Developmental Perspectives on Achievement Motivation, Personal and Contextual Influences. Fq 454-455.

Keller,J,M. (1983) "Motivational systems". San Francicisco: Jossey-Bass. 
Krueger, R.A (1994). "Focus groups: A Practical Guide for Applied Research". $2^{\text {nd }}$ ed. Thousand Oaks: Sage

Leary, M.(1999) "The social and psychological importance of self-esteem," Journal of Personality and Social Psychology 70, 510-520.

MASH,(2007). "How to Develop the Adult Education in Albania?

Pallant.J. (2010). SPSS Survival Manual.(4 ${ }^{\text {th }}$ ed.). McGraw-Hill Companies

Senko,C. Durrik, M \& Harackiewicz,J. (2008). "Historical Perspectives and New Directions in Achievement Goal Theory, Understanding the effects of mastery and performance-approach goals", Fq 100-101

Shaughnessy \& Zechmeister (1998) "Research Methods in Psychology" $4^{\text {th }}$ edition

Skaalvik,E. \& Finbak, L (2001) "Adult education in Great Britain, Norway and Spain". MOBA Project, The Norwegian Institute for Adult Education.

Taylor,S.\&Bogdan, R (1984)"Introduction to qualitative research methods"2 ${ }^{\text {nd }}$ Edition. New York:Wiley

Tegnant,M.,\& Pogson, P. (1995) "Learning and change in the adult years: A Developmental Perspective. San Francisco: Jossey-Bass.

Thompson,S \& Schlehofer, M. (2008) "The many Sides of Control Motivation. Motives For High, Low, and Illusory Control", Fq 51-53

Welzel,D. (2008). Reasons Adults Go Back to School. 
